\title{
Predictive Validity of Teaching Efficacy Beliefs on Teaching-Learning Conceptions: A Study of Physical Education Teacher Candidates
}

\author{
Mustafa Kayıhan Erbaş ${ }^{1}$ \\ ${ }^{1}$ Faculty of Sport Science, Aksaray University, Aksaray, Turkey \\ Correspondence: Mustafa Kayıhan Erbaş, Faculty of Sport Science, Aksaray University, Aksaray, Turkey. E-mail: \\ kayihan@aksaray.edu.tr
}

Received: November 20, 2020 Accepted: December 22, 2020 Online Published: December 30, 2020

doi:10.5539/jel.v10n1p61

URL: https://doi.org/10.5539/jel.v10n1p61

\begin{abstract}
This study aimed to determine the relationship between the teaching efficacy of physical education teacher candidates and their teaching-learning conceptions and to determine the validity of the level of teaching efficacy predicting teaching-learning conceptions. The study group consisted of 433 teacher candidates studying in physical education and sport teaching departments. The study revealed that teacher candidates' teaching efficacy levels and their adoption of constructivist conceptions were high and that teacher efficacy levels were important predictors of teaching-learning conceptions.
\end{abstract}

Keywords: teaching efficacy, teaching-learning conceptions, physical education teacher education

\section{Introduction}

Social cognitive theory has attracted the attention of researchers on this issue. Bandura (1997) stated that the main determinant of the choices people make is self-efficacy. Consequently, Pajares (1992) stated that self-efficacy beliefs offer people an instrumental mechanism to achieve their goals in their environment. Thanks to many studies carried out in this direction, reflections on the concept of teaching have emerged and teaching efficacy has begun to be discussed (Ross, 1992; Zach, Harari, \& Harari, 2012). There are studies and discussions on how to measure teaching efficacy, many of which have yielded important results (Tschannen-Moran, Woolfolk-Hoy, \& Hoy, 1998). Teaching efficacy, which reflects a teacher's belief that they process the knowledge, skills and abilities needed to direct learners to success, has been revealed to be an important factor affecting the learning and teaching process (Gencay, 2009; Sikula, 1996). It has been determined that teaching efficacy affects both a teacher's methods and choices, and students' beliefs about learning and their abilities. Teachers with strong efficacy tend to exhibit a high level of planning and organisation (Francois, 2020). Researchers studied teachers' efficacy beliefs for nearly 40 years, and it was found that there are relationships between a teacher's sense of efficacy regarding teaching and many outcomes, including student achievement (Skaalvik \& Skaalvik, 2014).

Studies on teaching efficacy show that there are generally two different dimensions or factors: personal teaching efficacy and general education efficacy. However, there is no common understanding on this issue; there is not much discussion on the first dimension, while there are different opinions on the second dimension. For example, while Emmer and Hickman (1991) defined the second dimension as external effects, Riggs and Enochs (1990) preferred to define it as result expectation. Bandura (1986) described it as the outcome expectancy dimension and commented that the expected result of a person is not due to what others can achieve, but results from that person's abilities and expected performance level. Many studies have found that teaching efficacy beliefs directly affect the education and training process, and that these beliefs vary according to variables such as teaching fields, gender, culture and experience. In this direction, studies have been carried out in different fields such as science teaching and mathematics teaching, and in different cultures. Accordingly, field-specific measurement tools were developed or adapted according to the culture (Tümkaya \& Miller, 2020).

One of the teaching fields in which studies on teaching efficacy beliefs are conducted is the field of physical education (PE). In recent years, due to the rising incidence of obesity and the need for physical activity, the popularity of PE activities has increased and the variety of research in the field of PE has expanded accordingly. Studies have been conducted to examine and measure teaching efficacy beliefs specific to the field of PE, and to adapt measurement tools to different cultures. Martin and Kullina (2003) are believed to be the first researchers 
to examine in detail the self-efficacy beliefs specific to the field of PE, emphasising the inadequacy of the studies conducted in this field. The authors developed the "Physical Education Teachers' Physical Activity Self-Efficacy Scale" (PETPAS), which is a measurement tool for measuring self-efficacy beliefs specific to the field of PE. Based on the knowledge that the concept of self-efficacy differs according to culture, this scale has been adapted to different cultures (Gencay, 2009; Kudláček, Baloun, \& Jesina, 2020). Humpries et al. (2012) argued that Martin and Kullina (2003) focused too narrowly on PE self-efficacy beliefs and discussed these beliefs from a broader and multi-dimensional perspective. Some studies have adapted this new multidimensional perspective to different cultures. When this multi-dimensional perspective is examined in terms of PE teaching competence, the following dimensions are revealed: (a) efficacy about PE content knowledge, (b) efficacy for applying scientific knowledge in teaching PE, (c) efficacy about accommodating skill level differences, (d) efficacy for teaching students with special needs, (e) efficacy about instruction, (f) efficacy for using assessment and (g) efficacy for using technology (Humpries et al., 2012).

Efficacy about PE content knowledge refers to the knowledge gained about the content of the PE course and the self-reliance in conveying this knowledge. The second dimension; efficacy for applying scientific knowledge in teaching PE includes the ability to use the scientific knowledge learned from sub-disciplines in PE and sports sciences in practice, to plan and apply it in accordance with the current national PE standards and curriculum. The third dimension; efficacy about accommodating skill level differences is the ability to perceive the differences in students' skill levels and to plan and teach accordingly. The fourth dimension; efficacy for teaching students with special needs expresses the planning and application efficacy for students with special needs in a normal PE class. The fifth dimension; efficacy about instruction covers competence in using and managing the course area and tools effectively, course safety, motivation and communication skills. The sixth dimension; efficacy for using assessment refers to efficacies in terms of measurement and evaluation. The last dimension; efficacy for using technology covers the efficacies related to the use of technology in terms of planning, teaching and professional communication.

It has been stated that the learning and teaching process is influenced by teaching efficacy beliefs as well as a process directly related to teaching-learning conceptions. For teaching and learning conceptions, which are defined as teachers' beliefs about their preferred learning and teaching ways, it has been determined that there are generally two types of classification: traditional and constructivist (Aypay, 2011; Bahcivan, Gurer, Yavuzalp, \& Akayoğlu, 2019; Chan \& Elliot, 2004). According to the traditional conception, which is a teacher-centred approach, teachers see themselves as the source of knowledge and perceive students as passive receptors. This conception also approaches each individual from the same point of view, without considering individual differences. In contrast, the constructivist conception is a student-centred approach where students are seen as active participants in the learning process. This conception embodies an understanding that each individual is different and takes these differences into consideration. According to the constructivist approach, students create, interpret and reorganise information individually; each individual should be active in the learning process and responsible for their own learning. In this case, the teacher plays the role of a guide facilitating learning.

\subsection{Teaching Efficacy and Teaching-Learning Conception}

Studies show that teaching efficacy beliefs and teaching-learning conceptions are correlated with each other (Eren, 2010). It has been observed that the pre-service education and professional experiences of teachers affect their teaching-learning conceptions and accordingly their professional performance (Gibson \& Dembo, 1984).

In a study about teacher candidates (Yener \& Y1lmaz, 2017), it was concluded that teacher candidates' efficacy beliefs were effective in orientation towards alternative teaching conceptions. In addition, studies indicate that there are positive relationships between teacher candidates' teaching efficacies and teaching-learning conceptions (Bahcivan, 2014; Bahcivan \& Kapucu, 2014). Studies also show that the teaching competencies of teacher candidates are an important predictor of teaching-learning conceptions (Eren, 2009).

While studies have been conducted in other teaching fields, there is no study that directly examines the relationship between PE teaching efficacy and teaching-learning conceptions, taking into account the belief of PE teaching efficacy. However, the relationship between self-efficacy beliefs and alternative teaching conceptions, including in PE teacher candidates, has been examined (Ruys, Van Keer, \& Aelterman, 2010), and the effect of pre-service education and teaching experience on alternative teaching conceptions has been observed. There are also studies indicating that the early field experience of PE teacher candidates positively affects their teaching-learning conceptions (Cutner-Smith, 1996).

It is thought that determining the relationship between the teaching efficacy beliefs and teaching-learning conceptions of PE teacher candidates will contribute to the previous scientific studies and fill the gap in the field. 
In this direction, the purpose of this research is to determine the relationship between the teaching efficacy of the PE teacher candidates and their teaching-learning conceptions, and determine the predictive validity of teaching efficacy levels on their teaching-learning conceptions. At the same time, the study aims to examine teaching efficacy levels and teaching-learning conceptions according to gender and grade level variables.

\section{Method}

\subsection{Study Model}

The correlational survey model was used to determine the relationship between the teaching efficacy and the teaching-learning conceptions of PE teacher candidates in this study. The correlational survey model is used to identify the relationship between two or more variables and to gain insight into cause-effect relationships (Karasar, 2014).

\subsection{Procedure}

The data were collected shortly before coronavirus hit Turkey. Participants were given preliminary information about the data collection process during the data collection. In the collected scales, those containing missing or illegible information were separated and not evaluated. Data from the remaining scales were transferred to the SPSS 22.0 analysis program and the necessary analyses were performed.

\subsection{Participants}

Participants consisted of 433 prospective PE teachers in the 3rd and 4th grades at 11 different universities. The participants were selected due to the content of the data collection tools used. Descriptive statistics of the participants are given in Table 1.

Table 1. Descriptive statistics of the participants

\begin{tabular}{llll}
\hline Variables & & $\mathrm{f}$ & $\%$ \\
\hline Gender & Female & 146 & 33.7 \\
& Male & 287 & 66.3 \\
Grade & 3rd grade & 199 & 46 \\
& 4th grade & 234 & 54 \\
$M_{\text {age }}=21.304 \pm 1.923$ & $\mathrm{n}=433$ & \\
\hline
\end{tabular}

\subsubsection{The Physical Education Teacher Education Program in Turkey}

The general efficacies of the teaching profession for all teaching branches were determined by the Ministry of National Education (MEB, 2017). The general efficacy areas of the teaching profession are grouped under three main headings: (a) professional knowledge, (b) professional skills and (c) attitudes and values.

Include in these subsections the information essential to comprehend and replicate the study. Insufficient detail leaves the reader with questions; too much detail burdens the reader with irrelevant information. Consider using appendices and/or a supplemental website for more detailed information.

The Turkish Physical Education Teacher Education Program (PETE) is different from many countries' programs. It is a four-year program that qualifies teacher candidates to become PE teachers. PETE courses consist of three parts (Erbas, 2014): (1) field education courses $(60 \%$, i.e., volleyball, basketball, sports physiology), (2) teaching profession courses ( $25 \%$, i.e., classroom management, teaching practice) and (3) general culture courses $(15 \%$, i.e., computer technologies, foreign languages). Mainly, the general culture courses are taken in the 1 st grade, the field education courses in the 2 nd and 3rd grades and the teaching profession courses in the 4th grade (YOK, 2007).

\subsection{Data Collection Tools}

a) Personal information form: this form included items determining the genders, grades and sports branch of the $\mathrm{PE}$ teacher candidates who participated in this study.

b) Physical Education Teaching Efficacy Scale: The Physical Education Teaching Efficacy Scale was originally developed by Humpries et al. (2012) and was adapted to Turkish by Erbaş, Kalemoğlu-Varol and Ünlü (2014). It consists of 35 items on factors such as (a) efficacy about PE content knowledge, (b) efficacy for applying scientific knowledge in teaching PE, (c) efficacy about accommodating skill level differences, (d) efficacy for teaching students with special needs, (e) efficacy about instruction, (f) efficacy for using assessment and (g) efficacy for using technology. 
Participants respond to each statement in the scale using a Likert-type rating: (1) "I can't do this", (2) "I can do this at a medium level" and (3) "I can do this at a high level". All items of the scale consist of positive expressions. Researchers (Humpries et al., 2012) have used the test-retest method and internal consistency Cronbach's alpha parameters to calculate the reliability of the scale. The Cronbach's alpha parameter expressing the internal consistency of the items was calculated as .94 for the overall scale. For each sub-dimension, the Cronbach's alpha was calculated as follows: "efficacy about PE content knowledge" .73, "efficacy for applying scientific knowledge in teaching PE" .70, "efficacy about accommodating skill level differences" .76, "efficacy for teaching students with special needs" .77, "efficacy about instruction" .82, "efficacy for using assessment" .76 and "efficacy for using technology" .84.

In this study, the internal consistency coefficients were calculated again and the Cronbach's alpha value for the overall scale was .82. The values for the sub-dimensions were as follows: "efficacy about PE content knowledge" .74, "efficacy for applying scientific knowledge in teaching PE" .78, "efficacy about accommodating skill level differences" .91, "efficacy for teaching students with special needs" .73, "efficacy about instruction" .77, "efficacy for using assessment".75 and "efficacy for using technology" .73.

c) Teaching and Learning Conceptions Questionnaire: The Teaching and Learning Conceptions Questionnaire, originally developed by Chan and Eliot (2004) and adapted to Turkish by Aypay (2011), consist of 30 items and two sub-dimensions: (a) constructivist understanding and (b) traditional understanding. Scale items use a 5-point Likert-type scale: (5) strongly agree, (4) agree, (3) undecided, (2) disagree and (1) strongly agree. The higher score obtained from the sub-factors is interpreted as adopting the understanding represented. Aypay (2011) measured the reliability of the scale with the Cronbach's alpha coefficient and split-half methods. The reliability of the overall scale was found to be .71 , for the sub-dimensions .88 and .83 , and the correlation between the two halves was found to be .77 .

Internal consistency coefficients for this study were re-calculated. The Cronbach's alpha value was calculated as .77 for the overall scale, .77 for the constructivist understanding sub-dimension and .74 for the traditional understanding sub-dimension.

\subsection{Data Analysis}

The distribution of the research data was examined before its analysis. The data fit the normal distribution; a Kolmogorov-Smirnov test with Lilliefors, histogram graph and normal distribution curve were determined by skewness and kurtosis, and further analyses were made accordingly. Descriptive statistics were used for the analysis of the data in this research.

In order to compare the teaching efficacy beliefs of PE teacher candidates and their teaching-learning conceptions according to gender and class variables, an independent samples t-test was conducted for the difference between arithmetic means. The correlation technique was used to determine the direction and level of the relationship between the teaching efficacy beliefs of PE teacher candidates and their teaching-learning conceptions. In addition, the regression analysis technique was used to test whether the sub-dimensions of teaching efficacy predicted teaching-learning conceptions.

\section{Results}

In this section, the findings are analysed in six subsections: (a) PE teacher candidates' levels of teaching competence and learning and teaching understanding, (b) comparison of teaching competencies and learning and teaching conceptions of PE teacher candidates by gender, (c) comparison of teaching competencies and learning and teaching conceptions of PE teacher candidates by class level, (d) the relationship between teaching competence and learning and teaching conceptions, (e) the predictive validity of the teaching competencies of the PE teacher candidates regarding traditional understanding levels, (f) the predictive validity of the teaching competencies of the PE teacher candidates regarding constructivist understanding levels.

\subsection{Teaching Efficacy and Teaching-Learning Conception Levels of Physical Education Teacher Candidates}

Arithmetic averages of PE teacher candidates' levels of teaching efficacy and its sub-dimensions and teaching-learning conceptions were calculated (Table 2). 
Table 2. Teaching efficacy and teaching-learning conception levels

\begin{tabular}{lll}
\hline Variables (n=433) & $\boldsymbol{M}$ & SD \\
\hline Efficacy about PE Content Knowledge & 1.806 & 0.394 \\
Efficacy for Applying Scientific Knowledge in Teaching PE & 1.907 & 0.465 \\
Efficacy about Accommodating Skill Level Differences & 2.489 & 0.456 \\
Efficacy for Teaching Students with Special Needs & 2.102 & 0.834 \\
Efficacy about Instruction & 2.573 & 0.561 \\
Efficacy for Using Assessment & 2.213 & 0.464 \\
Efficacy for Using Technology & 2.552 & 0.412 \\
Teaching Efficacy (Total) & 2.254 & 0.329 \\
Traditional Conception & 3.127 & 0.473 \\
Constructivist Conception & 4.126 & 0.449 \\
\hline
\end{tabular}

The arithmetic mean of the teaching efficacy levels of PE teacher candidates is high, with the highest value for the efficacy about instruction sub-dimension. The arithmetic averages of the efficacy levels are also high in the sub-dimensions of efficacy for using technology, efficacy about accommodating skill level differences, efficacy for using assessment and efficacy for teaching students with special needs. In the efficacy for applying scientific knowledge in teaching PE and efficacy about PE content knowledge sub-dimensions, the arithmetic averages of the efficacy levels are at a medium level.

When the arithmetic means of teaching-learning conceptions are examined (Table 2), it can be seen that the constructivist conception has a higher value than the traditional conception.

\subsection{Comparison of the Teaching Efficacy and Teaching-Learning Conception Levels of Physical Education Teacher Candidates According to Gender}

A homogeneity test was performed in order to understand whether the teaching efficacy and teaching-learning conceptions of PE teacher candidates varied according to gender. The results showed that the variances were homogenous. An independent t-test for arithmetic means was performed in independent groups (Table 3).

Table 3. Comparison of the arithmetic mean of teaching efficacy and teaching-learning conceptions according to gender

\begin{tabular}{|c|c|c|c|c|c|c|c|}
\hline Variables & Gender & $\mathrm{n}$ & $M$ & SD & Df & $\mathrm{t}$ & $\mathrm{p}$ \\
\hline \multirow[t]{2}{*}{ Efficacy about PE Content Knowledge } & Female & 146 & 1.874 & 0.418 & 431 & 2.540 & $.011 * *$ \\
\hline & Male & 287 & 1.772 & 0.377 & & & \\
\hline Efficacy for Applying Scientific Knowledge in Teaching & Female & 146 & 2.015 & 0.452 & & 3.503 & $.001 * *$ \\
\hline $\mathrm{PE}$ & Male & 287 & 1.851 & 0.462 & & & \\
\hline \multirow[t]{2}{*}{ Efficacy about Accommodating Skill Level Differences } & Female & 146 & 2.561 & 0.348 & & 2.356 & $.019 * *$ \\
\hline & Male & 287 & 2.453 & 0.498 & & & \\
\hline \multirow[t]{2}{*}{ Efficacy for Teaching Students with Special Needs } & Female & 146 & 2.295 & 1.240 & & 3.482 & $.001 * *$ \\
\hline & Male & 287 & 2.004 & 0.493 & & & \\
\hline \multirow[t]{2}{*}{ Efficacy about Instruction } & Female & 146 & 2.555 & 0.347 & & -0.474 & .635 \\
\hline & Male & 287 & 2.583 & 0.643 & & & \\
\hline \multirow[t]{2}{*}{ Efficacy for Using Assessment } & Female & 146 & 2.230 & 0.381 & & 0.534 & .594 \\
\hline & Male & 287 & 2.204 & 0.502 & & & \\
\hline \multirow[t]{2}{*}{ Efficacy for Using Technology } & Female & 146 & 2.532 & 0.396 & & -0.719 & .473 \\
\hline & Male & 287 & 2.563 & 0.421 & & & \\
\hline \multirow[t]{2}{*}{ Teaching Efficacy (Total) } & Female & 146 & 2.310 & 0.294 & & 2.555 & $.011 * *$ \\
\hline & Male & 287 & 2.225 & 0.342 & & & \\
\hline \multirow[t]{2}{*}{ Traditional Conception } & Female & 146 & 3.156 & 0.557 & 431 & 0.893 & .372 \\
\hline & Male & 287 & 3.113 & 0.424 & & & \\
\hline \multirow[t]{2}{*}{ Constructivist Conception } & Female & 146 & 4.178 & 0.563 & & 1.727 & .085 \\
\hline & Male & 287 & 4.099 & 0.377 & & & \\
\hline
\end{tabular}

Note. ${ }^{*} \mathrm{p}<0.05 ; * * \mathrm{p}<0.01$

Table 3 shows that significant differences were found according to gender. The average scores of the female candidates are higher than those of the male candidates in terms of total level of teaching efficacy and four sub-dimensions: efficacy about PE content knowledge, efficacy for applying scientific knowledge in teaching PE and efficacy about accommodating skill level differences and efficacy for teaching student with special needs. 
There are no significant differences between female and male candidates for the other teaching efficacy sub-dimensions and teaching-learning conceptions.

\subsection{Comparison of the Teaching Efficacy and Teaching-Learning Conception Levels of Physical Education Teacher Candidates According to Grade Level}

A homogeneity test was performed in order to understand whether the teaching efficacy and teaching-learning concepts of PE teacher candidates varied according to grade. The results showed that the variances were homogenous. An independent t-test for arithmetic means was performed in independent groups (Table 4).

Table 4. Comparison of the arithmetic mean of teaching efficacy and teaching-learning conceptions according to grade level

\begin{tabular}{|c|c|c|c|c|c|c|c|}
\hline Variables & Grade & $\mathrm{n}$ & $M$ & SD & Df & $\mathrm{t}$ & $\mathrm{p}$ \\
\hline \multirow[t]{2}{*}{ Efficacy about PE Content Knowledge } & 3 & 199 & 1.814 & 0.427 & 431 & 0.347 & .729 \\
\hline & 4 & 234 & 1.800 & 0.364 & & & \\
\hline \multirow[t]{2}{*}{ Efficacy for Applying Scientific Knowledge in Teaching PE } & 3 & 199 & 1.895 & 0.484 & & -0.466 & .641 \\
\hline & 4 & 234 & 1.916 & 0.448 & & & \\
\hline \multirow[t]{2}{*}{ Efficacy about Accommodating Skill Level Differences } & 3 & 199 & 2.462 & 0.485 & & -1.149 & .251 \\
\hline & 4 & 234 & 2.512 & 0.429 & & & \\
\hline \multirow[t]{2}{*}{ Efficacy for Teaching Students with Special Needs } & 3 & 199 & 2.013 & 0.494 & & -2.065 & $.040^{*}$ \\
\hline & 4 & 234 & 2.178 & 1.035 & & & \\
\hline \multirow[t]{2}{*}{ Efficacy about Instruction } & 3 & 199 & 2.510 & 0.491 & & -2.163 & $.031 *$ \\
\hline & 4 & 234 & 2.627 & 0.610 & & & \\
\hline \multirow[t]{2}{*}{ Efficacy for Using Assessment } & 3 & 199 & 2.209 & 0.473 & & -0.179 & .858 \\
\hline & 4 & 234 & 2.217 & 0.458 & & & \\
\hline \multirow[t]{2}{*}{ Efficacy for Using Technology } & 3 & 199 & 2.566 & 0.451 & & 0.648 & .518 \\
\hline & 4 & 234 & 2.541 & 0.377 & & & \\
\hline \multirow[t]{2}{*}{ Teaching Efficacy (Total) } & 3 & 199 & 2.227 & 0.314 & & -1.540 & .124 \\
\hline & 4 & 234 & 2.276 & 0.340 & & & \\
\hline \multirow[t]{2}{*}{ Traditional Conception } & 3 & 199 & 3.153 & 0.431 & 431 & 1.055 & .292 \\
\hline & 4 & 234 & 3.105 & 0.505 & & & \\
\hline \multirow[t]{2}{*}{ Constructivist Conception } & 3 & 199 & 4.134 & 0.510 & & 0.340 & .734 \\
\hline & 4 & 234 & 4.119 & 0.391 & & & \\
\hline
\end{tabular}

Note. ${ }^{*} \mathrm{p}<0.05 ; * * \mathrm{p}<0.01$

Table 4 reveals the significant differences that were found according to grade level. The average scores of the 4th grade candidates are higher than those of the 3rd grade candidates in terms of two teaching efficacy sub-dimensions: efficacy for teaching students with special needs and efficacy about instructions. There are no significant differences between 3rd grade and 4th grade candidates for the other teaching efficacy sub-dimensions and teaching-learning conceptions.

3.4 The Relationship between the Teaching Efficacy Levels of Physical Education Teacher Candidates and Their Learning-Teaching Conceptions

In this section, the direction and level of the relationship between the teaching efficacy sub-dimensions of the PE teacher candidates and the traditional and constructivist conceptions are examined (Table 5). 
Table 5. Relationship between teaching efficacy sub-dimensions and teaching-learning conceptions

\begin{tabular}{|c|c|c|c|c|c|c|c|c|c|}
\hline Variables & (A) & (B) & (C) & (D) & (E) & $(\mathrm{F})$ & (G) & $(\mathrm{H})$ & (I) \\
\hline (A) & 1 & & & & & & & & \\
\hline (B) & $.253 * *$ & 1 & & & & & & & \\
\hline (C) & $.250 * *$ & $.526^{* *}$ & 1 & & & & & & \\
\hline (D) & $.128 * *$ & $.120^{*}$ & $.170 * *$ & 1 & & & & & \\
\hline (E) & .025 & $.450^{* *}$ & $.560 * *$ & $.290 * *$ & 1 & & & & \\
\hline (F) & $.220 * *$ & $.455^{* *}$ & $.506^{* *}$ & $.304^{* *}$ & $.566^{* *}$ & 1 & & & \\
\hline (G) & -.045 & $.220 * *$ & $.350 * *$ & $.124 * *$ & $.415^{* *}$ & $.493 * *$ & 1 & & \\
\hline (H) & $.117^{*}$ & $.103^{*}$ & $.161^{* *}$ & $.114^{*}$ & $.180 * *$ & $.344 * *$ & $.177 * *$ & 1 & \\
\hline (I) & -.026 & .092 & .050 & $.095^{*}$ & $.300 * *$ & .071 & $.257 * *$ & $.205^{* *}$ & 1 \\
\hline$M$ & 1.806 & 1.907 & 2.489 & 2.102 & 2.573 & 2.213 & 2.552 & 3.127 & 4.126 \\
\hline SD & 0.394 & 0.465 & 0.456 & 0.834 & 0.561 & 0.464 & 0.412 & 0.473 & 0.449 \\
\hline \multicolumn{10}{|c|}{$* * \mathrm{p}<0.01, * \mathrm{p}<0.05$} \\
\hline (A) & \multicolumn{9}{|c|}{ Efficacy About PE Content Knowledge } \\
\hline (B) & \multicolumn{9}{|c|}{ Efficacy For Applying Scientific Knowledge In Teaching PE } \\
\hline (C) & \multicolumn{9}{|c|}{ Efficacy About Accommodating Skill Level Differences } \\
\hline (D) & \multicolumn{9}{|c|}{ Efficacy For Teaching Students With Special Needs } \\
\hline (E) & \multicolumn{9}{|c|}{ Efficacy About Instruction } \\
\hline (F) & \multicolumn{9}{|c|}{ Efficacy For Using Assessment } \\
\hline (G) & \multicolumn{9}{|c|}{ Efficacy For Using Technology } \\
\hline$(\mathrm{H})$ & \multicolumn{9}{|c|}{ Traditional Conception } \\
\hline (I) & \multicolumn{9}{|c|}{ Constructivist Conception } \\
\hline
\end{tabular}

Table 5 shows that there is a low-level positive correlation between the traditional conception and teaching efficacy sub-dimensions. The teaching efficacy sub-dimension that has the highest level of relationship with the traditional conception is the efficacy for using assessment $(\mathrm{r}=0.344, \mathrm{p}<0.01)$.

Regarding the constructivist conception, there is a low-level positive correlation between this conception and the teaching efficacy sub-dimensions efficacy for instruction $(r=0.300, p<0.01)$, efficacy for using technology $(r=$ $0.257, \mathrm{p}<0.01)$ and efficacy for teaching students with special needs $(\mathrm{r}=0.095, \mathrm{p}<0.05)$.

\subsection{The Predictive Validity of the Teaching Efficacy Levels of Physical Education Teacher Candidates} Regarding Their Traditional Conception Levels

Regression analysis was conducted to test the predictive validity of the traditional conception regarding teaching efficacy sub-dimensions of PE teacher candidates (Table 6).

Table 6. Regression analysis results regarding the prediction for traditional conception

\begin{tabular}{|c|c|c|c|c|c|c|c|}
\hline Variables & B & $\begin{array}{l}\text { Standard } \\
\text { Error }\end{array}$ & $\beta$ & $\mathrm{t}$ & $\mathrm{p}$ & Dual $r$ & Partial $\mathrm{r}$ \\
\hline Constant & 2.283 & 0.180 & & 12.702 & .000 & & \\
\hline $\begin{array}{l}\text { Efficacy About PE Content } \\
\text { Knowledge }\end{array}$ & 0.072 & 0.060 & 0.060 & 1.199 & .231 & 0.117 & 0.058 \\
\hline $\begin{array}{l}\text { Efficacy For Applying Scientific } \\
\text { Knowledge In Teaching PE }\end{array}$ & -0.080 & 0.058 & -0.079 & -1.390 & .165 & 0.103 & -0.067 \\
\hline $\begin{array}{l}\text { Efficacy About Accommodating } \\
\text { Skill Level Differences }\end{array}$ & -0.003 & 0.064 & -0.003 & -0.045 & .964 & 0.161 & -0.002 \\
\hline $\begin{array}{l}\text { Efficacy For Teaching Students } \\
\text { With Special Needs }\end{array}$ & 0.002 & 0.028 & 0.004 & 0.091 & .928 & 0.114 & 0.004 \\
\hline Efficacy About Instruction & 0.005 & 0.053 & 0.006 & 0.089 & .929 & 0.180 & 0.004 \\
\hline Efficacy For Using Assessment & 0.359 & 0.065 & 0.353 & 5.520 & $.000 * *$ & 0.344 & 0.259 \\
\hline Efficacy For Using Technology & 0.024 & 0.062 & 0.021 & 0.391 & .696 & 0.177 & 0.19 \\
\hline $\begin{array}{ll}\mathrm{R}=0.354 & \mathrm{R}^{2}=0.125 \\
\mathrm{~F}=8.698 & \mathrm{p}=.000\end{array}$ & & & & & & & \\
\hline
\end{tabular}

When the findings in Table 6 are examined, the traditional conception prediction equation $(r=0.354, p<0.01)$ of teaching efficacy sub-dimensions is important. The variables that make up the teaching efficacy sub-dimensions explain $13 \%$ of the total variance in the traditional conception dimension. According to the 
standardised regression coefficient ( $(B)$, the importance of predictor variables of the traditional conception is ranked as follows: efficacy for using assessment, efficacy for applying scientific knowledge in teaching PE, efficacy about PE content knowledge, efficacy for using technology, efficacy about instruction, efficacy for teaching students with special needs and efficacy about accommodating skill level differences. When the results regarding the significance of the regression coefficients are examined, it can be seen that only the efficacy for assessment variable is a significant and important predictor of the traditional understanding dimension. Other variables do not have a significant effect. In line with all these results, it was determined that the sub-dimensions of teaching efficacy had a low association with traditional conception.

\subsection{The Predictive Validity of the Teaching Efficacy Levels of Physical Education Teacher Candidates Regarding Their Constructivist Conception Levels}

Regression analysis was conducted to test the predictive validity of the constructivist conception regarding teaching efficacy sub-dimensions of PE teacher candidates (Table 7).

Table 7. Regression analysis results regarding the prediction for constructivist conception

\begin{tabular}{|c|c|c|c|c|c|c|c|}
\hline Variables & B & $\begin{array}{l}\text { Standard } \\
\text { Error }\end{array}$ & $\beta$ & $\mathrm{t}$ & $\mathrm{p}$ & $\begin{array}{l}\text { Dual } \\
\mathrm{r}\end{array}$ & Partial $r$ \\
\hline Constant & 3.448 & 0.163 & & 21.209 & .000 & & \\
\hline $\begin{array}{l}\text { Efficacy About PE Content } \\
\text { Knowledge }\end{array}$ & -0.029 & 0.054 & -0.026 & -0.543 & .587 & -0.026 & -0.026 \\
\hline $\begin{array}{l}\text { Efficacy For Applying Scientific } \\
\text { Knowledge In Teaching PE }\end{array}$ & -0.053 & 0.052 & -0.055 & -1.026 & .305 & 0.092 & -0.050 \\
\hline $\begin{array}{l}\text { Efficacy About Accommodating } \\
\text { Skill Level Differences }\end{array}$ & -0.252 & 0.058 & -0.256 & -4.362 & $.000 * *$ & 0.050 & -0.207 \\
\hline $\begin{array}{l}\text { Efficacy For Teaching Students } \\
\text { With Special Needs }\end{array}$ & -0.023 & 0.025 & -0.043 & -0.940 & .348 & 0.095 & -0.046 \\
\hline Efficacy About Instruction & 0.191 & 0.048 & 0.238 & 3.956 & $.000 * *$ & 0.300 & 0.188 \\
\hline Efficacy For Using Assessment & 0.357 & 0.059 & 0.369 & 6.054 & .029 & 0.371 & 0.282 \\
\hline Efficacy For Using Technology & 0.090 & 0.056 & 0.082 & 1.593 & .112 & 0.257 & 0.077 \\
\hline $\begin{array}{ll}R=0.456 & R^{2}=0.208 \\
F=15.944 & p=.000\end{array}$ & & & & & & & \\
\hline
\end{tabular}

When the findings in Table 7 are examined, the constructivist understanding prediction equation $(\mathrm{r}=0.456, \mathrm{p}<$ 0.01 ) of the teaching efficacy sub-dimensions is important. The variables that make up the teaching efficacy sub-dimensions explain $21 \%$ of the total variance in the constructivist understanding dimension. According to the standardised regression coefficient ( () , the importance of predictor variables of the constructivist conception is ranked as follows: efficacy for using assessment, efficacy about accommodating skill level differences, efficacy about instruction, efficacy for using technology, efficacy for applying scientific knowledge in teaching PE, efficacy for teaching students with special needs and efficacy about PE content knowledge. When the results regarding the significance of the regression coefficients are examined, it can be seen that only the variables efficacy about accommodating skill level differences and efficacy about instruction are significant and important predictors of the constructivist conception dimension. Other variables do not have a significant effect. In line with all these results, it was determined that the sub-dimensions of teaching efficacy had a low association with constructivist conception.

\section{Discussion}

The findings revealed that in general, the teaching efficacy levels of the PE teacher candidates were high. When the sub-dimensions of teaching efficacy were examined, it was seen that the highest value was for the sub-dimension efficacy about instruction. The efficacy levels were also high in the sub-dimensions efficacy for using technology, efficacy about accommodating skill level differences, efficacy for teaching students with special needs and efficacy for using assessment. In the efficacy for applying scientific knowledge in teaching PE and efficacy about PE content knowledge sub-dimensions, the efficacy levels were at a medium level. Other studies support these results (Dilek \& Tezci, 2020; Giles, Byrd, \& Bendolph, 2016; Humpries et al., 2012; Kudáček, Baloun, \& Jesina, 2020; Mihael, Levi-Keren, Efrati-Virtzer, \& Cinamon, 2020).

Francois (2020) stated that pre-service teachers' feelings of efficacy differ according to some situations, and that the education and experience gained before service are effective in varying their sense of efficacy. In this study, 
it can be suggested that educational quality and experience are reflected in the results and therefore differ in some sub-dimensions.

When the teaching-learning concepts were examined, it was observed that the averages of the traditional conceptions are at a medium level and the averages of the constructivist conceptions are high. This finding showed that pre-service teachers adopted the constructivist conception to a great extent. In addition, it revealed that the teacher candidates either adopted the traditional conception less or were indecisive about this conception. This result is supported by some studies (Aypay, 2011; Chang, Cahn, Tang, \& Cheng, 2009), although different results were found in other studies (Chan \& Elliot, 2004). It is considered as a situation where older research is expected to yield different results, indicating that the constructivist conception has just begun to be adopted.

The average scores of the female candidates were higher than those of the male candidates in terms of total level of teaching efficacy and four sub-dimensions: efficacy about PE content, efficacy for applying scientific knowledge in teaching PE, efficacy about accommodating skill level differences and efficacy for teaching student with special needs. However, there were no significant differences between female and male candidates for the other teaching efficacy sub-dimensions efficacy about instruction, efficacy for using assessment and efficacy for using technology.

Some studies support this result (Mohamed Emam \& Al Mahdi, 2020; Valente, Lourenço, Alves, \& Lara, 2020). Some researchers found that the teaching efficacies of female teacher candidates and male prospective teachers showed different development (Wolters \& Daugherty, 2007): female teacher candidates were more patient than male candidates in the teaching process (Shaukat, Sharma, \& Furlonger, 2013), and female teacher candidates showed more efficacy beliefs (Mohamed Emam \& Al Mahdi, 2020). This study found similar results.

There were no significant differences between female and male candidates for the teaching-learning conceptions. Some studies (Bonastre, Muñoz, \& Timers, 2017; Chan, 2003; Şentürk \& Zeybek, 2019) support this result, while others (Aypay, 2011; Mahasneh, 2018; Oguz, 2008) found different results. When these studies are examined, it can be concluded that in general, female teacher candidates adopt the constructivist conception more, while male teacher candidates adopt the traditional conception more. This can be considered as a result of the fact that the constructivist conception has not yet started to be adopted in teacher training institutions in Turkey, and is therefore not yet fully reflected in teacher candidates.

The average scores of the 4th grade candidates were higher than those of the 3rd grade candidates in terms of two teaching efficacy sub-dimensions: efficacy for teaching students with special needs and efficacy about instruction. Gurvitch and Metzler's (2009) research supports this result; they noted that practical training increases the level of teaching efficacy of teacher candidates. It was thought that 4th grade teacher candidates in Turkey taking a teaching practice course in this class have the opportunity to work with experienced teachers in the field of practice and develop their efficacy to perceive differences in the skill levels of students in the field of practice and to plan and teach in this direction.

There were no significant differences between 3rd grade and 4th grade candidates for the other teaching efficacy sub-dimensions and teaching-learning conceptions. No other study supports this result. In similar studies (Aypay, 2011; Chan, 2003; Rodriguez \& Cano, 2007), it was stated that the belief in the constructivist conception increased as the grade level increased. Different from these results, Eren (2009) stated that 3rd grade teacher candidates adopted the constructivist conception more than 4th grade teacher candidates. Teacher candidates studying in Turkey must succeed in the exam after graduation in order to start teaching. The fact that teacher candidates were educated with the constructivist conception and subjected to an exam preparation process specific to the traditional conception may have had an effect on these results.

It was observed that there was a positive low-level relationship between the traditional conception of PE teacher candidates and the sub-dimensions of teaching efficacy. It was found that the sub-dimension of teaching efficacy, efficacy for using assessment had the highest level of relationship with the traditional conception. In some studies of teachers' and teacher candidates' conception of assessment (Barnes, Fives, \& Dacey, 2017), it was stated that their conception can sometimes have multiple beliefs that contradict each other. Although training was provided in Turkey in accordance with the constructivist conception, the continuation of the evaluation process with a more traditional conception may have led to this result.

A positive low level of association was observed between the constructivist conception and the sub-dimensions of teaching efficacy, efficacy for instruction, efficacy for using technology and efficacy for teaching students with special needs. Teachers who adopt a constructivist conception have students who are more active and make note of individual differences (Chan \& Elliott, 2004). The efficacy for student understanding of instruction for a child with special needs can be considered as an expected result due to the positive relationship observed. At the 
same time, studies explain the positive relationship between efficacy for using technology and the constructivist conception. Some researchers (Bahcivan et al., 2019; Sang, Valcke, Van Braak, \& Tondeur, 2010) noted that teacher candidates who adopt a constructivist conception are predisposed to using technology in education and adopting digital technologies.

The variables that make up the sub-dimensions of teaching efficacy accounted for $13 \%$ of the total variance in the traditional conception dimension. When the results regarding the significance of the regression coefficients were examined (Table 6), it was seen that only the efficacy for assessment variable was a significant and important predictor of the traditional conception dimension. Other variables did not have a significant effect. It is thought that the past experiences of PE teacher candidates have an effect on this result. Although there is a widespread impression that the constructivist conception has been adopted in Turkey, it seems that this does not reflect reality in terms of evaluation. Eren (2010) examined the relationship between the teaching-learning conceptions of teacher candidates and their understanding of assessment, finding that there was both compliance and incompatibility and that they had more than one contradictory conception about assessment.

The variables that make up the teaching efficacy sub-dimensions explained $21 \%$ of the total variance in the constructivist conception dimension. When the results regarding the significance of the regression coefficients were examined (Table 7), it was seen that only the variables efficacy about accommodating skill level differences and efficacy about instruction were significant and important predictors of the constructivist conception dimension. Other variables did not have a significant effect. There are studies that support this result. In a study conducted with teacher candidates (Eren, 2009), it was stated that teaching efficacy levels were an important predictor of the constructivist conception. In addition, it has been emphasised by some researchers (Kember, 1997; Swars, 2005) that the adoption of a constructivist conception is important in terms of communicating effectively with students and considering individual differences.

\section{Conclusion}

When teacher candidates reach their final year of study, they start to feel competent in terms of teaching thanks to the teacher education they receive. Until they reach this level, they go through a teacher education process in which the constructivist conception is predominant for four years. However, instructors cannot apply the constructivist conception in teacher training institutions in Turkey, which has negative effects. In addition, while the emphasis is placed on the constructivist conception in the contents of pre-service courses, measurement and assessment processes are not carried out accordingly. The examination, which is a condition for entering the teaching profession, supports the traditional conception rather than the constructivist one. This situation causes confusion among prospective teachers.

In line with the results mentioned above, lecturers working in teacher training institutions should be informed about the current education policy and they should constantly update themselves with in-service training. In addition, measurement and assessment processes applied to prospective teachers should be reviewed. In this way, teacher candidates who are trained can be expected to teach using a constructivist conception when they start their duties. At the same time, pre-service teachers' induction process should be reviewed and different alternatives should be opened to discussion.

In future research, a wider study that includes beliefs about the measurement and assessment process in addition to teaching efficacy beliefs will provide more concrete results.

\section{Acknowledgments}

I would like to thank all teacher candidates who contributed to this study. This article is dedicated to teachers who died of coronavirus during its writing.

\section{References}

Aypay, A. (2011). Öğretme ve öğrenme anlayışları ölçeğinin Türkiye uyarlaması ve epistemolojik inançlar ile öğretme ve öğrenme anlayışları arasındaki ilişkiler. Kuram ve Uygulamada Eğitim Bilimleri, 11(1), 7-29.

Bahcivan, E. (2014). Examining relationships among Turkish preservice science teachers' conceptions of teaching and learning, scientific epistemological beliefs and science teaching efficacy beliefs. Journal of Baltic Science Education, 13(6), 870-882.

Bahcivan, E., Gurer, M. D., Yavuzalp, N., \& Akayoglu, S. (2019). Investigating the relations among pre-service teachers' teaching/learning beliefs and educational technology integration competencies: A structural equation modeling study. Journal of Science Education and Technology, 28(5), 579-588. https://doi.org/10.1007/s10956-019-09788-6 
Bahcivan, E., \& Kapucu, S. (2014). Turkish preservice elementary science teachers' conceptions of learning science and science teaching efficacy beliefs: Is there a relationship? International Journal of Environmental and Science Education, 9(4), 429-442. http://doi.org/10.12973/ijese.2014.226a

Bandura, A. (1986). Social foundations of thought and action: A social cognitive theory. Englewood Cliffs, NJ: Prentice-Hall.

Bandura, A. (1997). Self-efficacy: The exercise of control. New York: W. H. Freeman and Company.

Barnes, N., Fives, H., \& Dacey, C. (2017). U. S. teachers' conceptions of the purposes of assessment. Teaching and Teacher Education, 65, 107-116. https://doi.org/10.1016/j.tate.2017.02.017

Bonastre, C., Muñoz, E., \& Timmers, R. (2017). Conceptions about teaching and learning of expressivity in music among Higher Education teachers and students. British Journal of Music Education, 34, 277-290. https://doi.org/10.1017/S0265051716000462

Chan, K. W. (2003). Hong Kong teacher education students' epistemological beliefs and approaches to learning. Research in Education, 69, 36-50. https://doi.org/10.7227/RIE.69.4

Chan, K. W., \& Elliott, R. G. (2004). Relational analysis of personal epistemology and conceptions about teaching and learning. Teaching and Teacher Education, 20, 817-831. https://doi.org/10.1016/j.tate.2004.09.002

Cheng, M. M. H., Chan, K. W., Tang, S. Y. F., \& Cheng, A. Y. N. (2009). Pre-service teacher education student' epistemological beliefs and their conceptions of teaching. Teaching and Teacher Education, 25, 319-322. https://doi.org/10.1016/j.tate.2008.09.018

Curtner-Smith, M. D. (1996). The impact of an early field experience on preservice physical education teachers' conceptions of teaching. Journal of Teaching in Physical Education, 15(2), 224-250. https://doi.org/10.1123/jtpe.15.2.224

Dilekli, Y., \& Tezci, E. (2020). A cross-cultural study: Teachers' self-efficacy beliefs for teaching thinking skills. Thinking Skills and Creativity, 35, 100624. https://doi.org/10.1016/j.tsc.2019.100624

Emmer, E. T., \& Hickman, J. (1991). Teacher efficacy in classroom management and discipline. Educational and Psychological Measurement, 51(3), 755-765. https://doi.org/10.1177/0013164491513027

Erbaş, M. K., Varol, Y. K., \& Ünlü, H. (2014). Beden eğitimi öğretim yeterliliği ölçeğinin türkçe uyarlaması: geçerlik ve güvenirlik çalışması. CBÜ Beden Eğitimi ve Spor Bilimleri Dergisi, 6(1), 16-27.

Eren, A. (2009). Examining the teacher efficacy and achievement goals as predictors of Turkish student teachers' conceptions about teaching and learning. Australian Journal of Teacher Education, 34(1), 69-87. https://doi.org/10.14221/ajte.2009v34n1.6

Eren, A. (2010). Consonance and dissonance between Turkish prospective teachers' values and practices: Conceptions about teaching, learning, and assessment. Australian Journal of Teacher Education, 35(3), 3-48. https://doi.org/10.14221/ajte.2010v35n3.3

Francois, J. (2020). The relationship between pre-service training and teaching self-efficacy for inclusive practices. Educational Considerations, 45(3), 1-14. https://doi.org/10.4148/0146-9282.2182

Gencay, O. A. (2009). Validation of the physical education teachers' physical activity self-efficacy scale with a Turkish sample. Social Behavior and Personality: An International Journal, 37(2), 223-230. https://doi.org/10.2224/sbp.2009.37.2.223

Gibson, S., \& Dembo, M. H. (1984). Teacher efficacy: A construct validation. Journal of Educational Psychology, 76, 569-582. https://doi.org/10.1037/0022-0663.76.4.569

Gurvitch, R., \& Metzler, M. W. (2009). The effects of laboratory-based and field-based practicum experience on pre-service teachers' self-efficacy. Teaching and Teacher Education, 25(3), 437-443. https://doi.org/10.1016/j.tate.2008.08.006

Humphries, C. A., Hebert, E., Daigle, K., \& Martin, J. (2012). Development of a physical education teaching efficacy scale. Measurement in Physical Education and Exercise Science, 16(4), 284-299. https://doi.org/10.1080/1091367X.2012.716726

Karasar, N. (2014). Bilimsel araştırma yöntemi. Ankara: Nobel Yayınları.

Kember, D. (1997). A reconceptualization of the research into university academics' conceptions of teaching. Learning and Instruction, 7, 225-275. https://doi.org/10.1016/S0959-4752(96)00028-X 
Kudláček, M., Baloun, L., \& Ješina, O. (2020). The development and validation of revised inclusive physical education self-efficacy questionnaire for Czech physical education majors. International Journal of Inclusive Education, 24(1), 77-88. https://doi.org/10.1080/13603116.2018.1451562

Mahasneh, A. M. (2018). Investigation of the relationship between teaching and learning conceptions and epistemological beliefs among student teachers from hashemite university in Jordan. European Journal of Contemporary Education, 7(3), 531-540. https://doi.org/10.13187/ejced.2018.3.531

Martin, J. J., \& Kulinna, P. H. (2003). The development of a physical education teachers' physical activity self-efficacy instrument. Journal of Teaching in Physical Education, 22, 219-232. https://doi.org/10.1123/jtpe.22.2.219

MEB [Ministry of National Education]. (2017). Öğretmenlik mesleği genel yeterlikleri. Ankara: Öğretmen Yetiştirme ve Geliştirme Genel Müdürlüğü.

Michael, R., Levi-Keren, M., Efrati-Virtzer, M., \& Cinamon, R. G. (2020). The contribution of field experience in special education programs and personal variables to the teaching self-efficacy of higher education students. Teacher Development, 24(2), 223-241. https://doi.org/10.1080/13664530.2020.1740311

Mohamed Emam, M., \& Al-Mahdy, Y. F. H. (2020). Teachers' efficacy for inclusive practices in the Sultanate of Oman: Effect of gender and teaching experience. School Psychology International, 41(2), 170-192. https://doi.org/10.1177/0143034319895062

Oguz, A. (2008). Investigation of Turkish trainee teachers' epistemological beliefs. Social Behavior and Personality, 36(3), 709-720. https://doi.org/10.2224/sbp.2008.36.5.709

Pajares, M. F. (1992). Teachers' beliefs and educational research: cleaning up a messy construct. Review of Educational Research, 67, 302-322. https://doi.org/10.3102/00346543062003307

Riggs, I. M., \& Enochs, L. G. (1990). Toward the development of an elementary teacher's science teaching efficacy belief instrument. Science Education, 74, 625-637. https://doi.org/10.1002/sce.3730740605

Rodriguez, L., \& Cano, F. (2007). The learning approaches and epistemological beliefs of university students: A cross-sectional and longitudinal study. Studies in Higher Education, 32(5), 647-667. https://doi.org/10.1080/03075070701573807

Ross, J. A. (1992). Teacher efficacy and the effects of coaching on student achievement. Canadian Journal of Education, 17, 51-65. https://doi.org/10.2307/1495395

Ruys, I., Van Keer, H., \& Aelterman, A. (2010). Collaborative learning in pre - service teacher education: An exploratory study on related conceptions, self - efficacy and implementation. Educational Studies, 36(5), 537-553. https://doi.org/10.1080/03055691003729021

Sang, G., Valcke, M., Van Braak, J., \& Tondeur, J. (2010). Student teachers' thinking processes and ICT integration: Predictors of prospective teaching behaviors with educational technology. Computers \& Education, 54(1), 103-112. https://doi.org/10.1016/j.compedu.2009.07.010

Senturk, C., \& Zeybek, G. (2019). Teaching-learning conceptions and pedagogical competence perceptions of teachers: A correlational research. Research in Pedagogy, 9(1), 65-80. https://doi.org/10.17810/2015.92

Shaukat, S., Sharma, U., \& Furlonger, B. (2013). Pakistani and Australian pre-service teachers' attitudes and self-efficacy towards inclusive education. Journal of Behavioural Sciences, 23(2), 1-16.

Sikula, J. (1996). Handbook of research on teacher education. Macmillan Library Reference USA, Simon \& Schuster Macmillan, 1633 Broadway, New York, NY 10019.

Skaalvik, E. M., \& Skaalvik, S. (2014) Teacher self-efficacy and perceived autonomy: Relations with teacher engagement, job satisfaction, and emotional exhaustion. Psychological Reports, 114, 68-77. https://doi.org/10.2466/14.02.PR0.114k14w0

Swars, S. L. (2005). Examining perceptions of mathematics teaching effectiveness among elementary preservice teachers with differing levels of mathematics teacher efficacy. Journal of Instructional Psychology, 32(2), 139.

Tschannen-Moran, M., Woolfolk-Hoy, A., \& Hoy, W. K. (1998). Teacher efficacy: Its meaning and measure. Review of Educational Research, 68, 202-248. https://doi.org/10.3102/00346543068002202

Tümkaya, G. S., \& Miller, S. (2020). The perceptions of pre- and in-service teachers' self-efficacy regarding inclusive practices: A systematised review. Elementary Education Online, 19(2), 1061-1077. 
https://doi.org/10.17051/ilkonline.2020.696690

Valente, S., Lourenço, A. A., Alves, P., \& Dominguez-Lara, S. (2020). The role of emotional intelligence capacity for teacher's efficacy and classroom management. CES Psicología, 13(2), 18-31. https://doi.org/10.21615/cesp.13.2.2

Wolters, C. A., \& Daugherty, S. G. (2007). Goal structures and teachers' sense of efficacy: Their relation and association to teaching experience and academic level. Journal of Educational Psychology, 99(1), 181-193. https://doi.org/10.1037/0022-0663.99.1.181

Yener, D., \& Yılmaz, M. (2017). Öğretmen adaylarının öğrenme öğretme anlayışları ve fen öğretimine yönelik özyeterlik inançları. Abant İzzet Baysal Üniversitesi Ĕ̈itim Fakültesi Dergisi, 17(2), 1016-1038. https://doi.org/10.17240/aibuefd.2017.17.30227-326612

YOK [Higher Education Institution]. (2007). Öğretmen yetişstirme ve eğitim fakülteleri. Ankara: Yükseköğretim Kurulu Yayınları.

Zach, S., Harari, I., \& Harari, N. (2012). Changes in teaching efficacy of pre-service teachers in physical education. Physical Education and Sport Pedagogy, 17(5), 447-462. https://doi.org/10.1080/17408989.2011.582491

\section{Copyrights}

Copyright for this article is retained by the author, with first publication rights granted to the journal.

This is an open-access article distributed under the terms and conditions of the Creative Commons Attribution license (http://creativecommons.org/licenses/by/4.0/). 